\title{
An Exploratory Study of the Career Drivers of Accounting Students
}

\author{
J. Roberto A. de Magalhaes, PhD., CPA, University of North Dakota, USA \\ Harold Wilde, Ph.D., CPA, University of North Dakota, USA
}

\begin{abstract}
The purpose of this study was to assess the relative importance of nine career drivers of undergraduate accounting students. Career drivers are motivational factors that influence students' choices of careers. Faculty, academic advisors, and employment recruiters, among others, can benefit from knowing what accounting students consider to be important career factors. The three most important career drivers are expertise, security, and search for meaning. We also attempted to assess if there are significant differences in the career drivers of male and female students. Our results indicated that there are statistically significant differences between male and female respondents in the career drivers of expertise, security, and search for meaning.
\end{abstract}

Keywords: Career Drivers; Accounting Education; Gender

\section{INTRODUCTION}

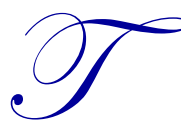

he recruitment and retention of qualified employees are among the most important concerns of accounting firms and other employers. Organizations are currently recruiting graduates who were born between 1980 and 2001, members of a generation known as the millennials. The primary purpose of this paper was to investigate the relative importance of certain career needs - referred to in this paper as career drivers - of today's undergraduate accounting students. In addition, we attempted to assess if there are significant differences in the career drivers of male and female students. The results of this study can be useful to students, faculty, career counselors, and college recruiters. College recruiters especially could benefit from understanding how career drivers influence students' initial career choices. Greater understanding of career drivers can improve employee selection and better match students with suitable employers. The remainder of this paper is organized as follows. The next section discusses the prior literature, which is followed by a discussion of the characteristics of the millennials generation, a discussion of the career drivers, an explanation of the research questions and methodology, and a discussion of the results. Finally, we present our conclusions and recommendations for further study.

\section{PRIOR LITERATURE}

Over the years, scholars and business practitioners have studied factors affecting the career decisions of accounting students. Several studies have attempted to identify intrinsic, extrinsic, and other job factors that are important to accounting students. Intrinsic factors are related to the satisfaction one gets from a job which provides the opportunity to work in a dynamic environment that is intellectually challenging and encourages creativity. Intrinsic factors are different from financial and market-related factors which are extrinsic to the nature of the job itself. Financial and market-related factors are associated with job security, career prospects, salary, and benefits. Other factors include peer influence, previous work experience, employer location, proximity to family, and size of employer. Peer and parental influence, prior work experience, and performance in accounting courses at a university were considered in a few job decision studies (Gul, Andrew, Leong, \& Ismail, 1989; Rosen, Paolillo, \& Estes, 1982; Silverstone \& Williams, 1979).

In recent decades, research studies have identified important career decision factors, many of which are extrinsic factors. In one of the earliest studies, Carpenter \& Strewser (1970) identified the following characteristics 
as being important to U.S. students: nature of work, advancement opportunities, salaries, working conditions, job security, training, and fringe benefits. In a study by Reed \& Kratchman (1989) students ranked the following highly: opportunity for growth and self-fulfillment, pay, taking responsibility for one's work, and relations with supervisors. Students in a study by Lanthan, Ostrowski, \& Pavlock (1987) ranked the following as being most important for choosing an employer: promotion opportunities, friendly personnel, high future earnings, training, and continuing professional education programs. Various studies found that financial compensation, job availability, job security and opportunities for advancement were found to be important factors in career decision (Cangelosi, Condie, \& Luthy, 1985; Felton, Buhr, \& Northey, 1994; Gul, et al., 1989; Haswell \& Holmes, 1988; Horowitz \& Riley, 1990; Kochanek \& Norgaard, 1985; Linden, 1987; Reha \& Lu, 1985; Rosen, et al., 1982; Shivaswamy \& Hanks, 1985). Felton et al. (1994) found that market-related job factors were valued significantly more by students who opted for careers in public accounting. In Bundy and Norris (1992) students ranked the following attributes as most important in choosing employment: job security, interesting work, advancement potential, health insurance benefits, and the personality of firm employees. In Tandy and Moores (1992) students ranked opportunities for career advancement as the most important factor when choosing an entry-level position.

On the question of the importance of intrinsic factors, prior studies concluded with mixed results. (Rosen, et al., 1982), (Haswell \& Holmes, 1988), and (Gul, et al., 1989) noted that accounting students consider intrinsic factors as less important in career decisions. By contrast, (Linden, 1987), (Horowitz \& Riley, 1990) and (Felton, et al., 1994) found intrinsic factors to be very important in career decisions made by accounting students. Linden (1987) found that the need for achievement and an interesting job are important motivating factors for choosing accounting as a career in New Zealand.

Studies by Chia et al. (2008 and 2003) investigated the importance of certain job factors, called career drivers, to accounting students in Singapore, Australia, and Hong Kong (2008), and to auditors in Hong Kong (2003). The comparative study of accounting students concluded that there were significant differences between male and female students on the importance of the following career drivers: search for meaning, job security, material rewards and creativity. The authors also noted significant differences in the importance of five career drivers: expertise, status, security, affiliation, and creativity among groups based on demographic factors such as nationality. The study of junior auditors concluded that there were significant differences between male and female students on the importance of the following career drivers: material rewards, search of meaning, and affiliation. The authors also found differences in the importance of certain career factors depending on job affiliation of the respondents (big- five firms versus non-big-five firms). Our study extends the research of Chia et al. (2008) by surveying accounting students in the United States on the importance of career drivers.

\section{CHARACTERISTICS OF THE MILLENNIALS GENERATION}

There are four generations in the workplace today: Millennials, born between 1980 and 2001; Gen Xers, 1965 and 1979; Baby Boomers, 1946 and 1964; and Traditionalists, 1925 and 1945. Table 1 presents a comparison of the traits of the four generations. The challenge facing accounting firms and other employers currently is how to recruit and integrate millennials in their workforce. The values and preferences of each generation are shaped by shared experiences due to economic, political, social, and cultural circumstances. Millennials have been described as entitled, optimistic, civic minded, impatient, capable of multi-tasking, team oriented, influenced by close parental involvement, and valuing work-life balance. Work and life for millennials are not distinct and separated but the two intermingle. Yeaton (2008) noted that millennials have a strong sense of morality and civic duty, are technologically savvy and self-confident, possess high self-esteem, are not overly loyal to any organization, and desire to "have a life." Some of the generational characteristics of millennials at times seem to conflict. For example, while millennials desire to have workplace flexibility, they also need guidance and mentors to assist them in pursuing their goals.

In order to recruit the best and the brightest, accounting firms should understand what drives the career preferences of those who are being recruited to fill junior positions. Accounting firms already have had to adapt their recruitment and communications methods. Big Four accounting firms such a Ernst \& Young and KPMG, for example, incorporated You Tube and Facebook in their efforts to reach millennials. An employer's ability to identify the relative importance of factors affecting students' employment choices may impact the success of its 
recruitment and retention strategies. This study attempted to identify the relative importance of certain career drivers in accounting students' job decisions.

\section{CAREERS DRIVERS}

Our study is motivated primarily by the research of Dave Francis (1985) who identified nine career drivers from his Richmond Survey: a study he conducted in the United Kingdom during 1984 and 1985. Francis concluded from his research that a "career driver is an inner force which determines what you want and what you need from your working life." The Richmond survey was based on extensive interviews with fifty three men and women ranging in age from 18 to 61 from a wide range of middle-class occupations, from clerical to professional. Each participant in the study was interviewed for about two hours to assess his or her career history and aspirations. Francis's methodology was based on the work done in the 1970s by Professor Edgar Schein of MIT who interviewed forty-four graduates from the Sloan School of Management for his study entitled "Career Anchors and Career Paths: A Panel Study of Management School Graduates" (Van Maanen (ed.) 1977). Francis identified the following nine career drivers: material rewards, power/influence, search for meaning, creativity, affiliation, autonomy, security, and status (Table 2).

Career drivers are not consciously selected but are determined by an individual's personality, abilities, values and self-image. Francis (1985, p. 46) describes career drivers as the "unseen hand that guides personal decision-making." Francis noted that as individuals experience significant life changes, the relative importance of some career drivers also may change. A business owner, who was included in Francis's study, felt that material achievement was so important that he even engaged in tax evasion. Then, while on a trip, this individual met an American missionary who helped him realize that his life was empty despite his business success. The business owner subsequently came clean with the tax authorities and no longer considered material gains to be the highest priority in his life. As the students in our study mature, we expect that the relative importance of their career drivers may well change.

\section{METHODOLOGY AND RESEARCH QUESTIONS}

Our study is based on an anonymous survey, conducted from 2009 to 2012, of 302 upper-level accounting students at the University of North Dakota (176 males and 126 females). We used the survey instrument designed by Francis (1985, pp. 51-58) to measure he relative importance of nine career drivers. The survey instrument contains 72 statements grouped in 36 pairs that are presented randomly. Please refer to appendix 1 for the full text of the survey instrument. Participants are asked to rate the relative importance of each statement in a pair and to allocate 3 points between the statements. For example, the first statement in a pair may be assigned a value of $0,1,2$, or 3 , with the balance of the points being assigned to the second statement. Regardless of how the points are allocated, it is critical that the points allocated to a pair of statements add to no more or less than 3 points. Each of the nine career drivers is associated with 8 of the 72 statements included in the instrument. Since the maximum that could be allocated to a single statement is 3 points, the most any given career driver could score is 24 points. This assumes that every one of the 8 statements associated with the driver receives 3 points.

The following is an example of a pair of statements:

a. I am prepared to do most things for material reward.

b. I see work as a means of enriching my personal development.

This study, which is the first to employ Francis's methods to investigate the career drivers of accounting students in the United States, attempted to answer the following research questions:

1) Are some career drivers relatively more important than others? If so, which drivers are relatively more important?

2) Is the relative importance of some career drivers significantly associated with gender? 
Our data analyses methods are the same used by Y.M. Chia et al. (2008). We used the general linear model (GLM) method to analyze our data because the number of subjects in each gender group is unequal resulting in an unbalanced experimental design. First, we used the score of the career drivers as the dependent variable and assessed whether at least two of the drivers were significantly different from each other. Then, once we established that at least two drivers were significantly different, we employed the Duncan multiple range test to perform multiple comparisons and to identify which drivers were significantly different.

\section{RESULTS}

Our first research question focused on the relative importance of career drivers to a group that included both male and female accounting students. The results of our analysis of variance (ANOVA), presented in Table 3, suggest that there are significant differences in the relative importance of some career drivers $(\mathrm{F}=62.18, \mathrm{p}<.00)$. The results of the Duncan multiple range test, presented in Table 4, indicate which drivers are significantly more important. Career drivers with mean scores of 12 or higher are considered to be above average. Based on the mean score rankings shown in Table 4, the three most important career drivers, in order of importance, are: 1) expertise (14.99), 2) security (14.05), and 3) search for meaning (13.38). Since these career drivers fall in different Duncan subsets, they are considered significantly different from each other. By contrast, power/influence and autonomy, which belong to Duncan subset 4 simultaneously, are not significantly different from each other. Power/influence and status, which belong to Duncan subset 3 simultaneously, also are not significantly different from each other. The three other career drivers (affiliation, material rewards, and creativity) were significantly different from each other.

Our second research question focused on whether there are differences in the relative importance of career drivers to male and female respondents. The results of our multiple comparisons, presented in Table 5, show significant differences in the mean scores of various career drivers between gender groups. There are significant differences in the mean scores of the three most important career drivers: expertise, job security, and search for meaning. Female respondents had a higher mean score in search for meaning (14.46), job security (14.79), and expertise (15.84) than male respondents whose mean scores for these career drivers were: 12.61, 13.52, and 14.37, respectively. The female respondents' mean score for expertise (15.84), shown in Table 5, was the highest career driver mean score. Although expertise was ranked highest in importance by both gender groups (Table 4), female respondents scored expertise significantly higher than did male respondents. Perhaps this result reflects a belief among female respondents that expertise is critical to their professional credibility and career advancement, especially in a profession that is largely male-dominated at the higher ranks.

There were no significant differences among the following career drivers whose mean scores from male and female respondents fell in the same Duncan subsets: creativity (Duncan subset 2), status (Duncan subset 5), power/influence (Duncan subset 5), and affiliation (Duncan subset 7). On the other hand, the mean scores of male and female respondents were significantly different for the following career drivers: material rewards, autonomy, search for meaning, security, and expertise. Male respondents had a higher mean score for material rewards (10.30) than female respondents (7.49). Perhaps due to cultural reasons, male respondents still place more emphasis on material gains than do female respondents. The mean score of female respondents for material rewards (7.49) was the lowest career driver score reported in Table 5. Male respondents had a higher score for autonomy (12.09) than female respondents (11.23).

\section{CONCLUSIONS AND RECOMMENDATIONS FOR FURTHER STUDY}

Because this paper provides insights into the career needs of accounting students, its results will be helpful to employment recruiters, career advisors, and academics. We found, for example, that expertise and job security are important to the millennials we surveyed - these career drivers also were important to prior generations. In addition, search for meaning is highly important to our respondents. Our results corroborate some of the findings in the study of junior auditors in Hong Kong by Chia et al. (2003). The auditors in that study rated search for meaning and expertise highly; however, they did not rate job security highly. One should keep in mind that our survey was conducted while the United States was experiencing a severe economic recession that began in 2008. Adverse economic conditions may have caused our students to consider job security as an important job decision factor. Our study also revealed that male and female respondents rated search for meaning and expertise differently, despite the 
high importance of these career drivers to both gender groups. Neither gender group rated material rewards highly. However, we do not believe that our students consider this career driver to be altogether unimportant. Our students may be confident of earning competitive salaries upon graduation and consider other career drivers to be relatively more important.

Although creativity, status, power/influence, autonomy, and affiliation were not rated highly, students may reconsider the relative importance of these career drivers later in life. Most accounting students surveyed are interested in developing the knowledge, skills, and aptitudes that will help them become successful in their careers. They are focused on passing professional certification exams, learning professional standards, and acquiring the skills they will need as auditors, tax advisors, or business consultants. As these young professionals mature and compete for promotions and positions of leadership, power/influence, status, and autonomy may become relatively more important to them.

There are some limitations one should consider when interpreting the results of our study. First, although the survey instrument developed by Francis was used in research on career drivers by Chia et al. and in this study, it has not been widely adopted. It would be desirable to see the survey instrument used in more empirical studies. Second, this study is based on a survey of students at a single university in the northern region of the United States; its results may not be generalizable to the entire country. The scope of this research should be extended to include students from other regions of the country. Finally, further research should investigate if there are significant differences in the career drivers of individuals based on their employment preferences (public or corporate accounting), or other demographic factors not considered in this study.

\section{AUTHOR INFORMATION}

J. Roberto A. de Magalhaes Ph.D., CPA is Assistant Professor of Accountancy at the University of North Dakota's College of Business and Public Administration. He is licensed as a CPA by Maryland and North Dakota. He earned a bachelor degree from Georgetown University's School of Foreign Service and a doctoral degree in accounting from the University of Mississippi.

Harold Wilde, Ph.D., CPA is Associate Professor of Accountancy at the University of North Dakota's College of Business and Public Administration. He is past president of the North American Accounting Society and past president of the North Dakota State Board of Accountancy. He earned a doctoral degree in accounting from the University of Nebraska at Lincoln.

\section{REFERENCES}

Alsop, R. (2008). The Trophy Kids Grow up : How the Millennial Generation Is Shaking up the Workplace. San Francisco[New York]: Jossey-Bass.

Bundy, P., \& Norris, D. (1992). What Accounting Students Consider Important in the Job Selection Process. Jounal of Applied Business Research, 82(2), 1-6.

Cangelosi, J. S., Condie, F. A., \& Luthy, D. H. (1985). The Influence of Introductory Accounting Courses on Career Choices. Delta Pi Epsilon, 9(Summer), 60-68.

Carpenter, C. G., \& Strewser, R. H. (1970). Job selection preferences of accounting students. The Journal of Accountancy, 9(1), 84-86.

Chia, Y. M. (2003). Career drivers of junior auditors: an exploratory study. [Article]. Managerial Auditing Journal, $18(2), 100-111$.

Chia, Y. M., Hian Chye, K., \& Pragasam, J. (2008). An international study of career drivers of accounting students in Singapore, Australia and Hong Kong. [Article]. Journal of Education \& Work, 21(1), 41-60. doi: $10.1080 / 13639080801957014$

Felton, S., Buhr, N., \& Northey, M. (1994). Factors Influencing the Business Student's Choice of a Career in Chartered Accountancy. [Article]. Issues in Accounting Education, 9(1), 131.

Francis, D. L. (1985). Managing your own career. London: Fontana/Collins.

Gul, F. A., Andrew, B. H., Leong, S. C., \& Ismail, Z. (1989). Factors Influencing Choice of Discipline of Study Accountancy, Engineering, Law and Medicine. Accountant and Finance, 29(2), 93-101. 
Haswell, S., \& Holmes, S. (1988). Accounting Graduate Employment Choice. ICA Journal (Australia), 53(2), 6367.

Horowitz, K., \& Riley, T. (1990). How Do Accounting Students See US. Accountancy, September, 75-77.

Kochanek, R., \& Norgaard, C. T. (1985). Student Perceptions of Alternative Accounting Careers - Part I. The CPA Jounal, 55(5), 36-43.

Lanthan, M. H., Ostrowski, B. A., \& Pavlock, E. J. (1987). Recruiting Entry-Level Staff: Gender Differences. The CPA Jounal, 57(1), 30-42.

Linden, Y. V. D. (1987). An Investigation into Students' Motivations for Selecting Accounting As a Career. Working Paper No. 58. Department of Accounting and Finance. Massey University. New Zealand.

Reed, S. A., \& Kratchman, S. H. (1989). A Longitudinal and Cross-Sectional Study of Students' Perceptions of the Importance of Job Attributes. Jounal of Accounting Education, 7(2), 171-193.

Reha, R. K., \& Lu, D. (1985). What Does It Take to Be Successful in Accounting? Business Education Forum, February, 24-28.

Rosen, L. S., Paolillo, J. G. P., \& Estes, R. W. (1982). An Empirical Analysis of Career Choice Factors Among Accountants, Attorneys, Engineers, and Physicians. Accounting Review, 57(4), 785.

Shivaswamy, M. K., \& Hanks, G. F. (1985). What do accounting students look for in a job? Management Accounting, 66(June), 60-61.

Silverstone, R., \& Williams, A. (1979). Recruitment, Training, Employment and Careers of Women Chartered Accountants in England and Wales. Accounting and Business Research, 9(33), 105-121.

Tandy, P. R., \& Moores, T. (1992). What Accountants Look for in a Job. The National Public Accountant, 37(3), 28-33.

Van Maanen (ed.), J. (1977). Organizational careers : some new perspectives: Wiley.

Yeaton, K. (2008). Recruiting and Managing the 'Why?' Generation: Gen Y. [Article]. CPA Journal, 78(4), 68-72. 


\section{TABLES}

Table 1. Four Generations in the Workplace. Adapted from Alsop (2008, p. 5).

\begin{tabular}{|c|c|c|c|c|}
\hline & Millennials & Gen Xers & Baby Boomers & Traditionalists \\
\hline Year of Birth Range & $1980-2001$ & $1965-1979$ & $1946-1964$ & $1925-1945$ \\
\hline $\begin{array}{l}\text { US Census Bureau } \\
\text { Estimate }\end{array}$ & 92 million & 62 million & 78.3 million & 38.6 million \\
\hline Generation Traits & $\begin{array}{l}\text { Entitled, optimistic, } \\
\text { civic minded, close } \\
\text { parental involvement, } \\
\text { work-life balance, } \\
\text { impatient, multitasking, } \\
\text { team oriented. }\end{array}$ & $\begin{array}{l}\text { Self-reliant, adaptable, } \\
\text { cynical, distrusts } \\
\text { authority, resourceful, } \\
\text { entrepreneurial, } \\
\text { technology savvy. }\end{array}$ & $\begin{array}{l}\text { Workaholic, idealistic, } \\
\text { competitive, loyal, } \\
\text { materialistic, seeks } \\
\text { personal fulfilment, } \\
\text { values titles and the } \\
\text { corner office. }\end{array}$ & $\begin{array}{l}\text { Patriotic, dependable } \\
\text { conformist, respects } \\
\text { authority, rigid, socially } \\
\text { and financially } \\
\text { conservative, solid work } \\
\text { ethic. }\end{array}$ \\
\hline
\end{tabular}

Table 2. The Nine Career Drivers. Adapted from Francis (1985).

\begin{tabular}{ll}
\hline Material Rewards & $\begin{array}{l}\text { This person is motivated by tangible assets and possessions, including money, and will change jobs for } \\
\text { a better opportunity to pursue material rewards. The main concern of this person is wealth. }\end{array}$ \\
Power / Influence & $\begin{array}{l}\text { This person is motivated by exercising dominance over others and the need to influence policies and } \\
\text { resource allocation decisions. The main concern of this person is dominance. }\end{array}$ \\
Search for & This person is motivated to pursue personal fulfillment by contributing to something finer or greater \\
than oneself, such as helping someone else. The main concern of this person is contribution. \\
Expertise
\end{tabular}

Table 3. ANOVA Results of Importance of Career Drivers $(n=302)$

\begin{tabular}{lccc}
\hline \multicolumn{1}{c}{ Source } & Type III SS & $\boldsymbol{F}$-value & Prob. $\boldsymbol{F}$-value \\
\hline Career driver & 9954.68 & 126.28 & 0.000 \\
Gender & 0.00 & 0.00 & 1.000 \\
Career driver x gender & 1195.30 & 15.16 & 0.000 \\
Model $F=62.18, \mathrm{p}<0.000$ & & & \\
\hline
\end{tabular}


Table 4. Results of Duncan Multiple Range Tests for the Relative Importance of Career Drivers ( $\mathrm{n}=302)$

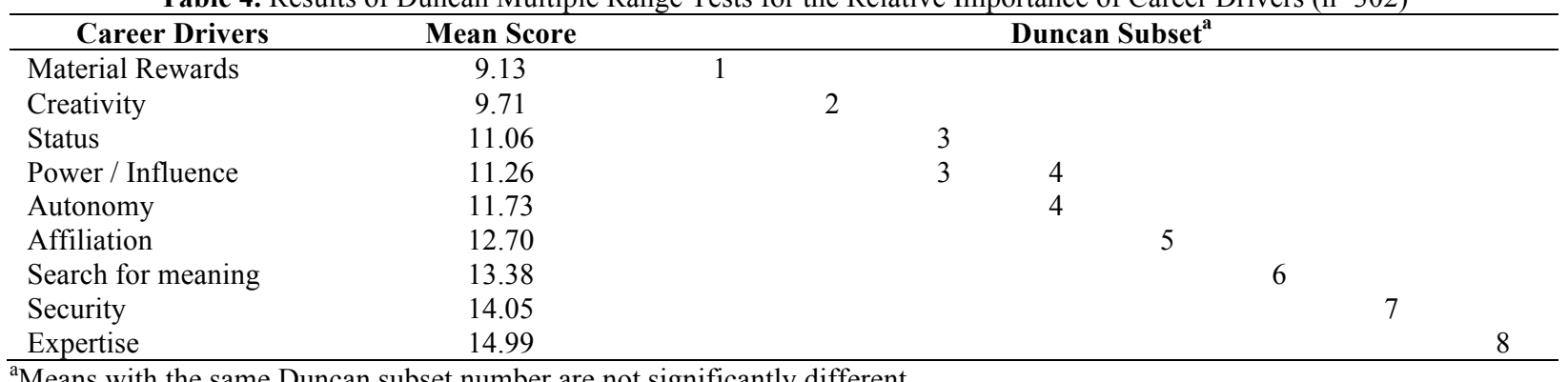

${ }^{\mathrm{a}}$ Means with the same Duncan subset number are not significantly different.

Table 5. Results of Duncan Multiple Range Tests for the Relative Importance of Career Drivers.

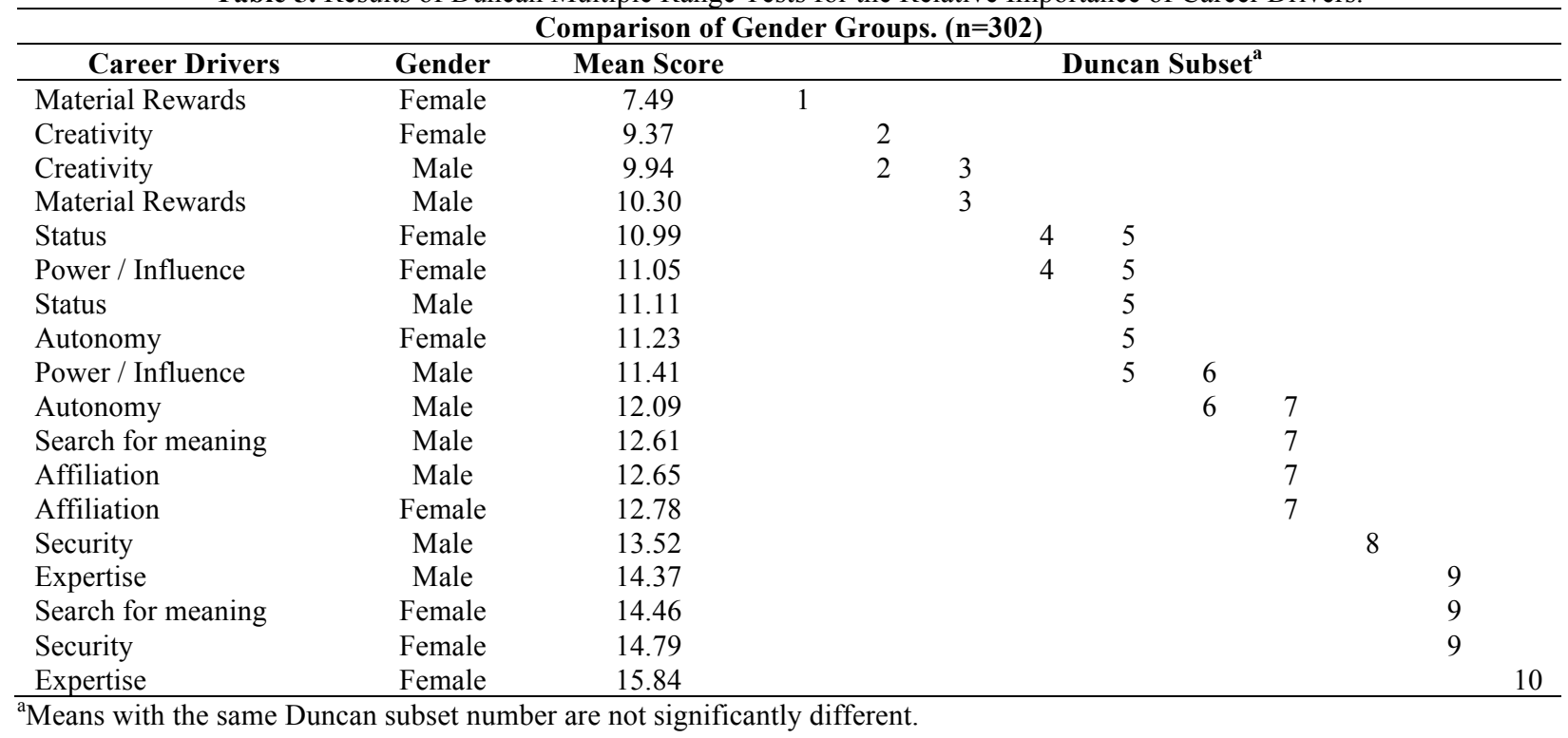




\section{APPENDIX 1 \\ Survey Questionnaire on Career Drivers (Francis, 1985)}

Listed below are thirty-six pairs of reasons often given by people when they are asked about what they want and need from their career. You must evaluate the relative importance to you of the statements within each pair and allocate three (3) points -- no more, no less. In other words, the possible distribution of points between the two items in the first pair, for example, may be as follows:
Alternative one: $\quad \mathrm{A}=3$ points
$\mathrm{B}=0$ points
Total $=3$ points.
Alternative two: $\quad \mathrm{A}=2$ points
$\mathrm{B}=1$ points
Total $=3$ points.
Alternative three: $\mathrm{A}=1$ points
$\mathrm{B}=2$ points
Total $=3$ points.
Alternative four:
$\mathrm{A}=0$ points
$\mathrm{B}=3$ points
Total $=3$ points

Points

1. a.__ I will only be satisfied with an unusully high standard of living.

b._I wish to have considerable influence over other people.

2. a.__ I only feel satisfied if the output from my job has real value in itself.

b._I want to be an expert in the things I do.

3. a._I want to use my creative abilities in my work.

b. It is especially important to me that I work with people whom I like.

4. a.__ I will obtain particular satisfaction by being able to freely choose what I do.

b.___ I want to make quite sure that I will be financially sound.

5. a._I enjoy feeling that people look up to me.

b. Not to put too fine a point on it, I want to be wealthy.

6. a._I want substantial leadership role.

b. I I do that which is meaningful to me, even though it may not gain tangible rewards.

7. a._I I want to feel that I have gained a hard-won expertise.

b.___ I want to create things which people associate with me alone.

8. a.__ I seek deep social relationships with other people in my work.

b.__ I will get satisfaction from deciding how I spend my time.

9. a._I will not be content unless I have ample material possessions.

b._I I want to demonstrate to my own satisfaction that I really know my discipline.

10. a. My work is part of my search for meaning in life.

b.__ I want the things that I produce to bear my name.

11. a._I seek to be able to afford anything I want.

b.__ A job with a long term security really appeals to me.

12. a._I seek a role which gives me substantial influence over others.

b._ I will enjoy being a specialist in my field. 
13. a._It is important to me that my work makes a positive contribution to the wider community.

b._Close relationships with other people at work are important to me.

14. a._I want my personal creativity to be extensively used.

b._I will prefer to be my own master.

15. a. Close relationships with other people at work will give me special satisfaction.

b._I want to look ahead in my life and feel confident that I will always be okay

16. a._I want to be able to spend money easily.

b._I want to be genuinely innovative in my work.

17. a._ Frankly, I want to tell other people what to do.

b._ For me, being close to others is really the important thing.

18. a._I look upon my career as part of a search for greater meaning in life.

b.__ I have found that I want to take full responsibility for my own decisions.

19. a._I will enjoy a reputation as a real specialist.

b. I will feel relax if I am in a secure career.

20 a._I desire the trappings of wealth.

b._I want to get to know new people through my work

21. a._I like to play roles which give me control over how others perform.

b.__ It is important that I can choose for myself the tasks that I undertake.

22. a. I will devote myself to work if I believe that the output will be worthwhile in itself.

b.___ I will take great comfort from knowing how I will stand on my retirement day.

23. a._ Close relationships with people at work will make it difficult for me to make a career move.

b.___ Being recognized as part of the "Establishment" is important to me.

24. a._I will enjoy being in charge of people and resources.

b._I I want to create things that no one else has done before.

25. a._ At the end of the day, I do what I believe is important, not that which simply promotes my career.

b._I seek public recognition.

26. a._I want to do something distinctly different.

b._I usually take the safe option.

27. a_ I want other people to look to me for leadership.

b._Social status is an important motivator for me.

28. a._A high standard of living attracts me.

b.__ I wish to avoid being tightly controlled by a boss at work.

29. a. I want my products to have my own name on them.

b._I seek formal recognition by others of my achievements. 
30. a. I prefer to be in charge.

b.__ I feel concerned when I cannot see a long way ahead in my career.

31. a__ I will enjoy being a person who had valuable specialist knowledge.

b.__ I will get satisfaction from not having to answer to other people.

32. a I dislike being a cog in a large wheel.

b._ It will give me satisfaction to have a high-status job.

33. a._I am prepared to do most things for material reward.

b.__ I see work as a means of enriching my personal development.

34. a._I want to have a prestigious position in my organization for which I work.

b. A secure future attracts me every time.

35. a. When I have congenial social relationships nothing else really matters.

b._B Being able to make an expert contribution will give me particular satisfaction.

36. a._I will enjoy the status symbols which come with senior positions.

b.__ I aspire to achieve a high level of specialist competence. 


\section{NOTES}

